\title{
Parasites of the Mink Frog (Rana septentrionalis) from Minnesota, U.S.A.
}

\author{
Anna M. Schotthoefer, ${ }^{1,5,6}$ Matthew G. Bolek, ${ }^{2}$ Rebecca A. Cole, ${ }^{3}$ and Val R. Beasley ${ }^{4}$ \\ ${ }^{1}$ Department of Pathobiology, University of Illinois at Urbana-Champaign, Urbana, Illinois 61802, U.S.A. \\ (e-mail: gve3@cdc.gov), \\ ${ }^{2}$ Department of Zoology, Oklahoma State University, Stillwater, Oklahoma 74078, U.S.A. (e-mail: bolek@okstate.edu), \\ ${ }^{3}$ USGS National Wildlife Health Center, 6006 Schroeder Road, Madison, Wisconsin 53711, U.S.A. \\ (e-mail: RCole@usgs.gov), and \\ ${ }^{4}$ Department of Veterinary Biosciences, University of Illinois at Urbana-Champaign, 2001 S Lincoln Ave., Urbana, Illinois \\ 61802, U.S.A. (e-mail: val@illinois.edu)
}

ABSTRACT: Twenty-two mink frogs, Rana septentrionalis, collected from two locations in Minnesota, United States, were examined for helminth and protozoan blood parasites in July 1999. A total of 16 parasite taxa were recovered including 5 larval digenean trematodes, 7 adult digenean trematodes, 3 nematodes, and 1 Trypanosoma species. Infracommunities were dominated by the digeneans in terms of richness and abundance. In particular, echinostomatid metacercariae in the kidneys of frogs were the most common parasites found, infecting $100 \%$ of the frogs and consisting of about $90 \%$ of all helminth individuals recovered. Gorgodera amplicava, Gorgoderina multilobata, Haematoloechus parviplexus, Haematoloechus breviplexus, Cosmocercoides dukae, and Oswaldocruzia pipiens represent new host records. The survey presented here represents the second known helminth survey of mink frogs conducted in North America. A summary of metazoan parasites reported from mink frogs is included.

KEY WORDS: Rana septentrionalis, mink frog, helminths, Minnesota, echinostomatid, Fibricola, plagiorchiid, Apharyngostrigea pipientis, Haematoloechus parviplexus, Haematoloechus longiplexus, Haematoloechus breviplexus, Gorgodera amplicava, Gorgoderina multilobata, Cephalogonimus americanus, Loxogenes arcanum, Oswaldocruzia pipiens, Cosmocercoides dukae, Trypanosoma pipientis.

The mink frog (Rana sepentrionalis) is a north temperate frog species, ranging in Canada from Manitoba to Labrador and the Maritime Provinces, south along the St. Lawrence River to northern New York, and west to south-central Minnesota in the United States (Casper, 2005). It is a member of the Aquarana Dubois 1992 clade (also known as the Rana catesbeiana group) as defined by Hillis and Wilcox (2005). The mink frog's closest extant relatives include the pig frog (Rana grylio), bullfrog (Rana catesbeiana), and green frog (Rana clamitans) (see Austin et al., 2003; Hillis and Wilcox, 2005). It is a highly aquatic frog, with a 1-2 year larval period (Casper, 2005).

Bacterial (Aegyptianella ranarum [Desser, 1987], Aeromonas spp. [Hedeen, 1972a]), viral (icosahedral viruses [Gruia-Gray et al., 1989; Desser, 1992]), and fungal (Batrachochytrium dendrobatidis [Longcore et al., 2007]) pathogens have been reported from

\footnotetext{
${ }^{5}$ Current address: Centers for Disease Control and Prevention, National Center for Zoonotic, Vector-Borne and Enteric Diseases, Division of Vector-Borne Infectious Diseases, 3150 Rampart Road, Fort Collins, Colorado 80521, U.S.A. (gve3@cdc.gov)

${ }^{6}$ Corresponding author.
}

mink frogs. Protozoan parasites, including intestinal coccidia, intracellular blood parasites, and trypanosomes, have also been reported (Werner and Walewski, 1976; Barta and Desser, 1984; Chen and Desser, 1989; Jones and Woo, 1989). However, there have been few reports of helminth parasites. Mace and Anderson (1975) reported that mink frogs were a paratenic host for the nematode, Dioctophyme renale, and Barta and Desser (1984) reported microfilariae of Foleyella sp. (currently designated as Waltonella sp. [Bain and Prod'hon, 1974]) in the blood. Sutherland (2005) and Wilson et al. (2005) also reported mink frogs as hosts for the metacercariae of Ribeioria ondatrae, which have been implicated in causing limb deformities in amphibians in North America (Johnson et al., 1999; Johnson et al., 2002) and, indeed, Sutherland (2005) found infections associated with limb deformities in mink frog populations of Minnesota. Conn et al. (2002) also reported mink frogs from upstate New York as hosts for echinostomatid metacercariae. The only known published survey of helminth parasites was conducted in 19481949 in northern Maine by Bouchard (1951). Here, we contribute to the known records of mink frog helminth parasites by reporting the results of a survey of parasites in frog samples from two locations in south-central Minnesota, United States. 


\section{MATERIALS AND METHODS}

Mink frogs $(n=22)$ were collected in July 1999 at two wetlands in south-central Minnesota, U.S.A. Site 1 was located in Stearns County at Birch Lake State Forest $\left(45^{\circ} 46^{\prime} 14.74^{\prime \prime} \mathrm{N}, 94^{\circ} 47^{\prime} 17.41^{\prime \prime} \mathrm{W}\right)$. Site 2 was a privately owned wetland in Todd County $\left(45^{\circ} 48^{\prime} 23.33^{\prime \prime} \mathrm{N}\right.$, $\left.94^{\circ} 50^{\prime} 42.61^{\prime \prime} \mathrm{W}\right)$. Captured frogs were held on ice and transported from Minnesota to Wisconsin, where they were held at $10^{\circ} \mathrm{C}$ until the time of necropsy (up to $6 \mathrm{~d}$ postcapture). After euthanasia by immersion in 1:500 tricaine methanesulfonate (MS-222), frogs were weighed to the nearest $0.01 \mathrm{~g}$ and their snout-vent lengths were recorded $(\mathrm{mm})$. Each frog was examined for ectoparasites and external abnormalities prior to necropsy. Blood films were collected and fixed in $100 \%$ methanol for later examination of blood parasites. The buccal and body cavities, internal organs, eyes, and skin were examined under stereomicroscopy for helminth parasites following standard protocols (Smyth and Smyth, 1980; Pritchard and Kruse, 1982). Parasite specimens recovered were isolated in amphibian's ringer solution (Smyth and Smyth, 1980) in small watch glasses, counted, and fixed in hot, $10 \%$ neutralbuffered formalin (NBF) or 95\% ethyl alcohol. Trematodes were prepared for identification using Semichon's acetocarmine stain, and nematodes were cleared in glycerine (Pritchard and Kruse, 1982). Blood films were stained with Giemsa and examined under $\times 400$ magnification; the number of fields of view inspected approximated 100,000 erythrocytes per frog. The carcasses of frogs were fixed in $10 \%$ NBF and cleared and stained using a modified method of Hanken and Wassersug (1981) for later identification and enumeration of encysted metacercariae in the musculature. This method has previously been used to detect and quantify metacercariae embedded in the musculature of amphibians (Sessions and Ruth, 1990). Recognition of the different metacercariae observed during necropsies was possible in the cleared and stained frogs due to the different staining patterns and other morphological characteristics that were preserved in the specimens (e.g., excretory vesicles, echinostomatid collar spines; A. M. Schotthoefer, personal observation). Identifications of adult taxa were made using original descriptions of parasites and related literature (Olsen, 1937; Lang, 1968; Ulmer, 1970; Baker, 1977; Schell, 1985; Vanderburg and Anderson, 1987a, 1987b, 1987c; McAlpine and Burt, 1998; Bolek and Janovy, 2007). Additionally, the paratype of Gorgoderina multilobata was borrowed from the H. W. Manter Parasitology Collection, University of Nebraska, Lincoln, Nebraska (HWML 23428) and compared to worms recovered from our study. Larval digeneans were identified based on descriptions in Chandler (1942), Ulmer (1970), Schell (1985), McAlpine and Burt (1998), and Sutherland (2005) and, in some cases, were identified only to order. Descriptions in Woo (1969) were used to identify the trypanosome species. Voucher specimens of parasites were deposited in the Harold W. Manter Laboratory of Parasitology, University of Nebraska-Lincoln (collection nos. HWML): Gorgoderina multilobata (49009), Gorgodera amplicava (49010), Cephalogonimus americanus (49011), Haematoloechus longiplexus (49012), Haematoloechus parviplexus (49013), Haematoloechus breviplexus (49014), Loxogenes arcanum (49015), undetermined echinostomatid (49016), Cosmocercoides dukae (4901749018), and Oswaldocruzia pipiens (49019). Cleared and stained frogs were deposited in the Bell Museum of Natural
History, University of Minnesota, Minneapolis-St. Paul, Minnesota (Collection nos. 14624-15168).

Prevalences, mean abundances, and intensities (sensu Bush et al., 1997) were calculated for each parasite taxa recovered. We also determined the taxa that dominated each infracommunity in terms of representing more than $50 \%$ of the individuals recovered per host.

\section{RESULTS}

Six (5 males:1 female) and 16 (9 males:7 females) mink frogs were collected and necropsied from Sites 1 and 2, respectively. The average weights and lengths $( \pm 1 \mathrm{SD})$ of frogs collected from Site 1 were 7.2 (3.72) g and $44.5(6.92) \mathrm{mm}$, respectively, and from Site 2 were $7.8(0.93) \mathrm{g}$ and $46.1(2.09) \mathrm{mm}$, respectively. All of the frogs examined were infected with at least one species of parasite. In total, 16 parasite taxa were recovered from the frogs examined; 5 of these taxa were larval digenean trematodes, 7 were adult digenean trematodes, 3 were nematodes, and 1 Trypanosoma species was detected in the blood (Table 1). Eleven taxa were found at Site 1, and 14 were found at Site 2 . On average ( $\pm 1 \mathrm{SD})$, frogs were infected with 4.0 (2.76) parasite taxa at Site 1 and 4.3 (1.61) taxa at Site 2.

Infracommunities ranged from 56 to 208 helminth individuals per frog at Site 1 and from 69 to 979 per frog at Site 2. Larval trematodes dominated the communities; approximately $90 \%$ of the helminths recovered at Site 1 were larval trematodes, as were about $96 \%$ of the helminths recovered at Site 2 . Echinostomatid metacercariae from the kidneys of frogs had the highest infrapopulations (Table 1) and dominated the infracommunities in 19 of the 22 $(86.4 \%)$ frogs examined. A metacercaria, identified as belonging to the Order Plagiorchiida, and found encysted in the body cavity on surfaces of visceral organs and in the musculature (referred to here as Plagiorchiid2), dominated the infracommunities of 3 of the $6(50 \%)$ frogs necropsied from Site 1 . On average $( \pm 1 \mathrm{SD})$, frogs were infected with $1.5(0.54)$ and 2.5 (0.73) larval trematode taxa, 1.5 (1.64) and 1.3 (1.00) adult trematode taxa, and $0.7(0.52)$ and 0.4 (0.63) nematode taxa at Sites 1 and 2, respectively. In general, adult trematode and nematode infrapopulations did not exceed 35 and 7 worms, respectively (Table 1).

\section{DISCUSSION}

The mink frog is a highly aquatic frog. Adults occur in permanent water bodies, especially where there are protected areas with abundant aquatic macrophytes (Hedeen, 1986; Casper, 2005). Individ- 
Table 1. Prevalence, mean abundance, and range of intensities of parasites found in 22 specimens of Rana septentrionalis from Minnesota, United States.

\begin{tabular}{|c|c|c|c|c|c|c|c|}
\hline \multirow[b]{2}{*}{ Parasite taxa (stage*) } & \multicolumn{3}{|c|}{ Site $1(n=6)$} & \multicolumn{3}{|c|}{ Site $2(n=16)$} & \multirow[b]{2}{*}{ Site(s) of infection } \\
\hline & $\begin{array}{l}\text { Prevalence } \\
(\%)\end{array}$ & $\begin{array}{c}\text { Mean } \\
\text { abundance } \\
( \pm 1 \text { SD })\end{array}$ & $\begin{array}{l}\text { Range of } \\
\text { intensities }\end{array}$ & $\begin{array}{c}\text { Prevalence } \\
(\%)\end{array}$ & $\begin{array}{c}\text { Mean } \\
\text { abundance } \\
( \pm 1 \text { SD })\end{array}$ & $\begin{array}{l}\text { Range of } \\
\text { intensities }\end{array}$ & \\
\hline \multicolumn{8}{|l|}{ Protozoa } \\
\hline Trypanosoma pipientis & 33.3 & & $1-12 \dagger$ & 6.3 & & 1 & Blood \\
\hline \multicolumn{8}{|l|}{ Trematoda } \\
\hline Echinostomatids $(\mathrm{L}) \$$ & 100 & $61.3(57.59)$ & $6-147$ & 100 & $379.9(265.78)$ & $40-972$ & Kidneys \\
\hline Fibricola sp. (L) & 0 & & & 62.5 & $7.1(12.56)$ & $1-51$ & Body cavity, musculature \\
\hline Apharyngostrigea pipientis (L) & 0 & & & 6.3 & $0.07(0.25)$ & 1 & Body cavity \\
\hline Unidentified Plagiorchiid1 (L) & 0 & & & 50 & $2.5(3.72)$ & $1-12$ & $\begin{array}{l}\text { Body cavity, } \\
\text { musculature, under } \\
\text { skin }\end{array}$ \\
\hline Unidentified Plagiorchiid2 (L) & 50 & $54.5(72.88)$ & $65-185$ & 31.3 & $0.8(1.44)$ & $1-5$ & $\begin{array}{l}\text { Body cavity, } \\
\text { musculature, under } \\
\text { skin }\end{array}$ \\
\hline $\begin{array}{l}\text { Haematoloechus } \\
\text { longiplexus }(\mathrm{A})\end{array}$ & 16.7 & $0.3(0.82)$ & 2 & 37.5 & $2.1(3.86)$ & $1-11$ & Lungs \\
\hline $\begin{array}{l}\text { Haematoloechus } \\
\text { parviplexus }(\mathrm{A})\end{array}$ & 33.3 & $2.3(4.80)$ & $2-12$ & 25 & $2.4(6.87)$ & $1-27$ & Lungs \\
\hline $\begin{array}{l}\text { Haematoloechus } \\
\text { breviplexus (A) }\end{array}$ & 0 & & & 6.3 & $0.06(0.25)$ & 1 & Lungs \\
\hline $\begin{array}{l}\text { Haematolechus sp. } \\
\quad \text { (immature A) }\end{array}$ & 16.7 & $0.2(0.41)$ & 1 & 25 & $0.7(1.45)$ & $1-5$ & Lungs \\
\hline $\begin{array}{c}\text { Cephalogonimus } \\
\text { americanus (A) }\end{array}$ & 50 & $6(8.00)$ & $4-18$ & 0 & & & Intestine \\
\hline Loxogenes arcanum (A) & 16.7 & $3.3(8.16)$ & 20 & 0 & & & $\begin{array}{l}\text { Wall of stomach at } \\
\text { pylorus, pancreas, } \\
\text { surface of liver }\end{array}$ \\
\hline Gorgodera amplicava (A) & 0 & & & 25 & $0.4(0.74)$ & $1-2$ & Bladder \\
\hline Gorgoderina multilobata (A) & 16.7 & $0.2(0.41)$ & 1 & 6.3 & $0.07(0.26)$ & 1 & Bladder \\
\hline Unidentified gorgoderid (A) & 0 & & & 6.3 & $0.07(0.26)$ & 1 & Bladder \\
\hline \multicolumn{8}{|l|}{ Nematoda } \\
\hline Oswaldocruzia pipiens (A) & 16.7 & $1.2(2.86)$ & 7 & 6.3 & $0.2(0.75)$ & 3 & Intestine, body cavity \\
\hline Cosmocercoides dukae (A) & 33.3 & $1.2(1.83)$ & $3-4$ & 25 & $0.4(0.72)$ & $1-2$ & Rectum \\
\hline Unidentified nematode $(\mathrm{J})$ & 16.7 & $0.3(0.82)$ & 2 & 12.5 & $0.3(0.77)$ & $1-3$ & Intestine \\
\hline
\end{tabular}

* Parasite stage recovered; L, larvae; J, juvenile; A, adult; includes gravid and non-gravid specimens.

$\uparrow$ Per 100,000 erthrocytes.

\$ May include members of the genera Echinostoma and Echinoparyphium.

uals are described as spending the majority of their time resting and foraging in water, often in a semisubmerged state, and their gut contents reflect a primarily aquatic diet (Hedeen, 1972b). They have been found in terrestrial habitats only after night rains (Hedeen, 1986). Larvae typically metamorphose after a 1-yr larval period, although 2-yr larval periods do occur (Hedeen, 1972c; Leclair and Laurin, 1996; Casper, 2005). The helminth communities found in the mink frogs from Minnesota were consistent with those previously reported for aquatic frogs. Frog species living a predominately aquatic existence tend to be infected with parasite communities that are dominated by trematode taxa, whereas the commu- nities found in terrestrial species are comprised largely of nematode and, sometimes, cestode taxa (Brandt, 1936; Rankin, 1945; Muzzall, 1991; McAlpine, 1997; Bolek and Coggins, 2003). In the mink frog individuals that we examined, the parasite communities were dominated by trematode species in terms of richness, prevalences, and abundances (Table 1). In particular, larval stages of trematodes were the most numerically abundant and, of the 3 taxonomic groups of helminths detected (e.g., larval trematode, adult trematode, and nematode), adult trematode species were the most species rich. Bouchard (1951) also found a diversity of trematode taxa infecting mink frogs in Maine and found that the 
prevalences and intensities of these infections were frequently higher in mink frogs than in the more terrestrial species examined from the same region (e.g., Bufo americanus, Rana pipiens, Rana sylvatica).

Many of the adult trematode taxa detected in our survey in Minnesota were also found in mink frogs in Maine (Bouchard, 1951; Table 2). However, we did not find Glypthelmins quieta, Haematoloechus medioplexus, Haematoloechus varioplexus (but see note Table 2), Megalodiscus temperatus, Halipegus sp., or Cylindrotaenia americana, as were reported for Maine mink frogs (Bouchard, 1951). The one blood parasite detected in our survey, Trypanosoma pipientis, was also previously reported in mink frogs in Ontario, Canada (Barta and Desser, 1984; Table 2); whereas G. amplicava, G. multilobata, H. parviplexus, $H$. breviplexus, C. dukae, and O. pipiens are new host records.

The helminth communities in mink frogs in Minnesota were comprised of parasite taxa that have frequently been reported to infect other anuran species (e.g., Ulmer, 1970; McAlpine and Burt, 1998). Exceptions are $H$. parviplexus and $L$. arcanum. Both of these species were first reported from bullfrogs by Stafford $(1900,1902)$ and have since been predominantly reported from bullfrogs, green frogs, and mink frogs (Bouchard, 1951; Williams and Taft, 1980; Muzzall, 1991; McAlpine and Burt, 1998; Bolek and Janovy, 2007), although Goldberg and Bursey (2007) recently reported $L$. arcanum from Rana (=Lithobates) vaillanti in Costa Rica. Bolek and Janovy (2007) demonstrated that $H$. parviplexus infects bullfrogs and green frogs, but that leopard frogs appear to be resistant to infection with this Haematoloechus species. Our finding of $H$. parviplexus in Minnesota mink frogs raises the possibility that $H$. parviplexus is an Aquarana Dubios 1992 specialist.

It is possible that $L$. arcanum also represents a species that diverged and coevolved with the Aquarana Dubois 1992 clade. However, because it has also been reported to infect leopard frogs (Osborn, 1912; Crawford, 1938; Goldberg and Bursey, 2007), it is unlikely that it is an Aquarana specialist. Interestingly, however, we did not detect this species in over 500 leopard frogs examined from the same region, and during the same time period, as the mink frogs that were examined for the current study (Schotthoefer, 2003). Adults of L. arcanum are found encysted in the wall of the duodenum at the pylorus, although they may also be found associated with the liver or urinary bladder (Stafford, 1900;
Osborn, 1912; Crawford, 1938). Metacercariae of $L$. arcanum are transmitted to frogs in odonate naiads (Crawford, 1938).

Mink frog populations have recently been reported with high prevalences of limb abnormalities (Gardiner and Hoppe, 1999; Vandenlangenberg et al., 2003; Hoppe, 2005), and Sutherland (2005) found abnormalities associated with $R$. ondatrae infections. In the mink frog individuals we necropsied, no $R$. ondatrae infections were detected, and only 5 of $144(3.5 \%)$ mink frogs captured and examined for external abnormalities during a 3-yr study of 36 wetlands, including the 2 studied here, were observed with abnormalities (Schoff et al., 2003). Therefore, it does not appear that mink frogs in the region of Minnesota we studied are experiencing population constraints related to high abnormality rates.

In summary, mink frogs are somewhat unique among the ranid species of North America in having a range restricted to the high northern latitudes. The species is also described as being one of the most aquatic frogs in North America (Hedeen, 1986; Casper, 2005). Surprisingly, the helminth communities of the species have been little studied. Our examination reveals a helminth community dominated by larval and adult digenean trematodes, with the majority of species being shared with other ranid species. Comparative studies of the helminth communities of the mink frog, and its close relatives bullfrogs and green frogs, would provide insight into the roles of contemporary ecology and evolution in structuring anuran parasite communities in temperate climates.

\section{ACKNOWLEDGMENTS}

We would like to thank J. E. Murphy for collecting frogs, the late D. R. Sutherland for help in necropsying the frogs, and A. V. Koehler for reading blood films. We also greatly acknowledge A. Jiménez-Ruiz of the Harold W. Manter Laboratory of Parasitology, University of Nebraska State Museum, for providing specimens of gorgoderids for comparisons. Additionally, M.G.B. thanks Cedar Point Biological Station, University of NebraskaLincoln, for use of facilities. Funding was provided by a U.S. Environmental Protection Agency STAR (EPA: R82-5867) grant to V.R.B. Although the research described in this article has been funded in part by the EPA, it has not been subjected to any EPA review and, therefore, does not necessarily reflect the views of the Agency, and no official endorsement should be inferred. 
Table 2. Summary of the parasites of Rana septentrionalis in North America.*

\begin{tabular}{|c|c|c|c|}
\hline Parasite & $\begin{array}{c}\% \text { Prevalence } \\
\text { (number of hosts examined) }\end{array}$ & Location & Reference \\
\hline \multicolumn{4}{|l|}{ Protozoa } \\
\hline Trypanosoma pipientis & $\begin{array}{r}2.7(75) \\
43.5(46) \\
13.6(22)\end{array}$ & $\begin{array}{l}\text { Ontario, Canada } \\
\text { Guelph and Ontario, Canada } \\
\text { Minnesota }\end{array}$ & $\begin{array}{l}\text { Barta and Desser (1984) } \\
\text { Jones and Woo (1989) } \\
\text { This study }\end{array}$ \\
\hline Trypanosoma rotatorium & $\begin{array}{r}25.3(75) \\
8.7(23)\end{array}$ & $\begin{array}{l}\text { Ontario, Canada } \\
\text { Michigan }\end{array}$ & $\begin{array}{l}\text { Barta and Desser (1984) } \\
\text { Werner and Walewski } \\
\quad(1976)\end{array}$ \\
\hline Trypanosoma ranarum & $\begin{array}{l}2.2(46) \\
4.3(23)\end{array}$ & $\begin{array}{l}\text { Guelph and Ontario, Canada } \\
\text { Michigan }\end{array}$ & $\begin{array}{l}\text { Jones and Woo (1989) } \\
\text { Werner and Walewski } \\
\quad(1976)\end{array}$ \\
\hline Hepatozoon sp. & $8.0(75)$ & Ontario, Canada & Barta and Desser (1984) \\
\hline Lankesterella minima & $20.0(75)$ & Ontario, Canada & Barta and Desser (1984) \\
\hline Babesiasoma stableri & $18.6(75)$ & Ontario, Canada & Barta and Desser (1984) \\
\hline Eimeria algonquini & $10.3(68)$ & Ontario, Canada & Chen and Desser (1989) \\
\hline Eimeria kermiti & $1.5(68)$ & Ontario, Canada & Chen and Desser (1989) \\
\hline \multicolumn{4}{|l|}{ Trematoda } \\
\hline Echinostomatid metacercariae & $\begin{array}{l}100.0(22) \\
100.0(2)\end{array}$ & $\begin{array}{l}\text { Minnesota } \\
\text { New York }\end{array}$ & $\begin{array}{l}\text { This study } \\
\text { Conn et al. (2002) }\end{array}$ \\
\hline Fibricola sp. metacercariae & $45.5(22)$ & Minnesota & This study \\
\hline $\begin{array}{l}\text { Apharyngostrigea pipientis } \\
\text { metacercariae }\end{array}$ & $4.5(22)$ & Minnesota & This study \\
\hline Plagiorchiid metacercariae & $72.7(22)$ & Minnesota & This study \\
\hline Ribeiroia ondatrae metacercariae & $\begin{array}{l}\text { NR }+ \\
\text { NR }\end{array}$ & $\begin{array}{l}\text { Minnesota } \\
\text { Wisconsin }\end{array}$ & $\begin{array}{l}\text { Sutherland (2005) } \\
\text { Wilson et al. (2005) }\end{array}$ \\
\hline Cephalogonimus americanus & $\begin{array}{l}10.5(57) \\
13.6(22)\end{array}$ & $\begin{array}{l}\text { Maine } \\
\text { Minnesota }\end{array}$ & $\begin{array}{l}\text { Bouchard (1951) } \\
\text { This study }\end{array}$ \\
\hline Glypthelmins quieta & $40.4(57)$ & Maine & Bouchard (1951) \\
\hline Gorgoderina attenuata & $29.8(57)$ & Maine & Bouchard (1951) \\
\hline Gorgoderina simplex & $8.8(57)$ & Maine & Bouchard (1951) \\
\hline Gorgoderina translucida & $7.0(57)$ & Maine & Bouchard (1951) \\
\hline Gorgoderina multilobata & $9.1(22)$ & Minnesota & This study \\
\hline Gorgodera amplicava & $18.2(22)$ & Minnesota & This study \\
\hline Loxogenes arcanum & $\begin{array}{r}14.0(57) \\
4.5(22)\end{array}$ & $\begin{array}{l}\text { Maine } \\
\text { Minnesota }\end{array}$ & $\begin{array}{l}\text { Bouchard (1951) } \\
\text { This study }\end{array}$ \\
\hline Megalodiscus temperatus & $3.5(57)$ & Maine & Bouchard (1951) \\
\hline Haematoloechus longiplexus & $\begin{array}{l}42.1(57) \\
31.8(22)\end{array}$ & $\begin{array}{l}\text { Maine } \\
\text { Minnesota }\end{array}$ & $\begin{array}{l}\text { Bouchard (1951) } \\
\text { This study }\end{array}$ \\
\hline Haematoloechus medioplexus & $10.5(57)$ & Maine & Bouchard (1951) \\
\hline Haematoloechus varioplexus $\dagger$ & $5.3(57)$ & Maine & Bouchard (1951) \\
\hline Haematoloechus parviplexus & $27.3(22)$ & Minnesota & This study \\
\hline Haematoloechus breviplexus & $4.5(22)$ & Minnesota & This study \\
\hline Halipegus sp. & $28.1(57)$ & Maine & Bouchard (1951) \\
\hline \multicolumn{4}{|l|}{ Cestoda } \\
\hline Cylindrotaenia americana & $12.3(57)$ & Maine & Bouchard (1951) \\
\hline \multicolumn{4}{|l|}{ Nematoda } \\
\hline Oswaldocruzia pipiens & $9.1(22)$ & Minnesota & This study \\
\hline Cosmocercoides dukae & $27.3(22)$ & Minnesota & This study \\
\hline Waltonella sp. microfilaria & $1.3(75)$ & Ontario, Canada & Barta and Desser (1984) \\
\hline Dioctophyme renale juveniles & $9.6(146)$ & Ontario, Canada & Mace and Anderson (1975) \\
\hline
\end{tabular}

* Does not include intestinal protozoa reported by Camara and Buttrey (1961).

$\dagger$ Bouchard reported H. similiplexus in mink frogs, which is a synonym of $H$. varioplexus. However, it is unclear if Bouchard (1951) was dealing with $H$. varioplexus or $H$. parviplexus because no voucher specimens exist and $H$. parviplexus was originally described as $H$. varioplexus, and these names have been used interchangeably in the literature (see Bolek and Janovy, 2007).

$\$ N R$, not reported. 


\section{LITERATURE CITED}

Austin, J. D., S. C. Lougheed, P. E. Moler, and P. T. Boag. 2003. Phylogenetics, zoogeography, and the role of dispersal and vicariance in the evolution of the Rana catesbeiana (Anura: Ranidae) species group. Biological Journal of the Linnean Society 80:601-624.

Bain, O., and J. H. Prod'hon. 1974. Homogéneité des filaire de genre Waltonella, Ochoterenella und Madochotera; creation des Waltonellinae n.subfam. Annales de Parasitologie Humaine et Comparée 49:721-739.

Baker, M. R. 1977. Redescription of Oswaldocruzia pipiens Walton, 1929 (Nematoda: Trichostrongylidae) from amphibians of eastern North America. Canadian Journal of Zoology 55:104-109.

Barta, J. R., and S. S. Desser. 1984. Blood parasites of amphibians from Algonquin Park, Ontario. Journal of Wildlife Diseases 20:180-189.

Bolek, M. G., and J. R. Coggins. 2003. Helminth community structure of sympatric eastern American toad, Bufo americanus, northern leopard frog, Rana pipiens, and blue-spotted salamander, Ambystoma laterale, from southeastern Wisconsin. Journal of Parasitology 89:673-680.

Bolek, M. G., and J. Janovy, Jr. 2007. Evolutionary avenues for, and constraints on, the transmission of frog lung flukes (Haematoloechus spp.) in dragonfly second intermediate hosts. Journal of Parasitology 93: 593-607.

Bouchard, J. L. 1951. The platyhelminthes parasitizing some northern Maine Amphibia. Transactions of the American Microscopical Society 70:245-250.

Brandt, B. B. 1936. Parasites of certain North Carolina salientia. Ecological Monographs 6:491-532.

Bush, A. O., K. D. Lafferty, J. M. Lotz, and A. W. Shostak. 1997. Parasitology meets ecology on its own terms: Margolis et al. revisited. Journal of Parasitology 83:575-583.

Camara, J., and B. W. Buttrey. 1961. Intestinal protozoa from tadpoles and adults of the mink frog, Rana septentrionalis Baird. Proceeding of South Dakota Academy of Sciences 40:59-66.

Casper, G. S. 2005. Rana septentrionalis Baird, 1854(b) Mink frog. Pages 581-584 in M. J. Lannoo, ed., Amphibian Declines: The Conservation Status of United States Species. University of California Press, Berkeley and Los Angeles, California.

Chandler, A. C. 1942. The morphology and life cycle of a new strigeid, Fibricola texensis, parasitic in raccoons. Transactions of Microscopsical Society of Washington 61:156-167.

Chen, G. J., and S. S. Desser. 1989. The Coccidia (Apicomplexa: Eimeriidae) of frogs from Algonquin Park, with descriptions of two new species. Canadian Journal of Zoology 67:1686-1689.

Conn, D. B., A. Vargas-Martínez, and D. A. Conn. 2002. Helminth communities of six anuran (Amphibia) host species in the St. Lawrence River valley and northern Adirondack Mountains of New York state. Pages 623626 in Proceedings of the 10th International Congress of Parasitology. Monduzzi Editore, Bologna, Italy.

Crawford, W. W. 1938. Observations on the life cycle of Loxogenes arcanum Nickerson (Trematoda). Journal of Parasitology 24:35-44.
Desser, S. S. 1987. Aegyptianella ranarum sp. n. (Rickettsiales, Anaplasmataceae): ultrastructure and prevalence in frogs from Ontario. Journal of Wildlife Diseases 23: 52-59.

Desser, S. S. 1992. Ultrastructural observations on an icosahedral cytoplasmic virus in leukocytes of frogs from Algonquin Park Ontario. Canadian Journal of Zoology 70:833-836.

Gardiner, D. M., and D. M. Hoppe. 1999. Environmentally induced limb malformations in mink frogs (Rana septentrionalis). Journal of Experimental Zoology 284: 207-216.

Goldberg, S. R., and C. R. Bursey. 2007. Helminths of two species of frogs, Lithobates taylori and Lithobates vaillanti (Ranidae), from Costa Rica. Caribbean Journal of Science 43:65-72.

Gruia-Gray, J., M. Petric, and S. Desser. 1989. Ultrastructural biochemical and biophysical properties of an erythrocytic virus of frogs from Ontario Canada. Journal of Wildlife Diseases 25:497-506.

Hanken, J., and R. J. Wassersug. 1981. The visible skeleton. Functional Photography 16:22-26.

Hedeen, S. E. 1972a. Escape behavior and causes of death of the mink frog Rana septentrionalis. Herpetologica 28:261-262.

Hedeen, S. E. 1972b. Food and feeding behavior of the mink frog Rana septentrionalis in Minnesota. American Midland Naturalist 88:291-300.

Hedeen, S. E. 1972c. Post metamorphic growth and reproduction of the mink frog Rana septentrionalis. Copeia 1972:169-175.

Hedeen, S. E. 1986. The southern geographic limit of the mink frog, Rana septentrionalis. Copeia 1986:239244.

Hillis, D. M., and T. P. Wilcox. 2005. Phylogeny of the New World true frogs (Rana). Molecular Phylogenetics and Evolution 34:299-314.

Hoppe, D. M. 2005. Malformed frogs in Minnesota: history and interspecific differences. Pages 103-108 in M. J. Lannoo, ed., Amphibian Declines: The Conservation Status of United States Species. University of California Press, Berkeley and Los Angeles, California.

Johnson, P. T. J., K. B. Lunde, E. G. Ritchie, and A. E. Launer. 1999. The effect of trematode infection on amphibian limb development and survivorship. Science 284:802-804.

Johnson, P. T. J., K. B. Lunde, E. M. Thurman, E. G. Ritchie, S. N. Wray, D. R. Sutherland, J. M. Kapfer, T. J. Frest, J. Bowerman, and A. R. Blaustein. 2002. Parasite (Ribeiroia ondatrae) infection linked to amphibian malformations in the Western United States. Ecological Monographs 72:151-168.

Jones, S. R. M., and P. T. K. Woo. 1989. Use of kidney impressions for the detection of trypanosomes of Anura. Journal of Wildlife Diseases 25:413-415.

Lang, B. Z. 1968. The life cycle of Cephalogonimus americanus Stafford, 1902 (Trematoda: Cephalogonimidae). Journal of Parasitology 54:945-949.

Leclair, R., Jr., and G. Laurin. 1996. Growth and body size in populations of mink frogs Rana septentrionalis from two latitudes. Ecography 19:296-304.

Longcore, J. R., J. E. Longcore, A. P. Pessier, and W. A. Halteman. 2007. Chytridiomycosis widespread in 
anurans of northeastern United States. Journal of Wildlife Management 71:435-444.

Mace, T. F., and R. C. Anderson. 1975. Development of the giant kidney worm, Dioctophyma renale (Goeze, 1782) (Nematoda: Dictophymatoidea). Canadian Journal of Zoology 53:1552-1568.

McAlpine, D. F. 1997. Helminth communities in bullfrogs (Rana catesbeiana), green frogs (Rana clamitans), and leopard frogs (Rana pipiens) from New Brunswick, Canada. Canadian Journal of Zoology 75:1883-1890.

McAlpine, D. F., and D. B. Burt. 1998. Helminths of bullfrogs, Rana catesbeiana, green frogs, $R$. clamitans, and leopard frogs, $R$. pipiens in New Brunswick. Canadian Field-Naturalist 112:50-68.

Muzzall, P. M. 1991. Helminth infracommunities of the frogs Rana catesbeiana and Rana clamitans from Turkey Marsh, Michigan. Journal of Parasitology 77: 366-371.

Olsen, O. W. 1937. A new species of bladder fluke, Gorgoderina tanneri (Gorgoderidae: Trematoda), from Rana pretiosa. Journal of Parasitology 23:499-503.

Osborn, H. L. 1912. On some points on the organization of specimens of Loxogenes arcanum. Zoologische Anzeiger 39:550-556.

Pritchard, M. H., and G. O. W. Kruse. 1982. The collection and preservation of animal parasites. University of Nebraska Press, Lincoln, Nebraska. 141 pp.

Rankin, J. S., Jr. 1945. An ecological study of the helminth parasites of amphibians and reptiles of western Massachusetts and vicinity. Journal of Parasitology 31:142-150.

Schell, S. C. 1985. Handbook of Trematodes of North America North of Mexico. University Press of Idaho, Moscow, Idaho. 263 pp.

Schoff, P. K., C. M. Johnson, A. M. Schotthoefer, J. E. Murphy, C. Lieske, R. A. Cole, L. B. Johnson, and V. R. Beasley. 2003. Prevalence of skeletal and eye malformations in frogs from north-central United States: estimations based on collections from randomly selected sites. Journal of Wildlife Diseases 39:510 521.

Schotthoefer, A. M. 2003. Environmental, landscape, and host-related factors associated with parasitism and its effects on larvae and metamorphic frogs of Rana pipiens. Ph.D. Thesis. University of Illinois at UrbanaChampaign, Urbana, Illinois. 194 pp.

Sessions, S. K., and S. B. Ruth. 1990. Explanation for naturally occurring supernumerary limbs in amphibians. Journal of Experimental Zoology 254:38-47.
Smyth, J. D., and M. M. Smyth. 1980. Frogs as hostparasite systems. Macmillan Press, London, U.K. 112 pp.

Stafford, J. 1900. Some undescribed trematodes. Zoologische Jahrbucher 13:399-414.

Stafford, J. 1902. On the representation of Distomum variegatum. Zoologische Jahrbuecher Abteilung fuer Systematik Oekologie und Geographie der Tiere 16: 895-912.

Sutherland, D. R. 2005. Parasites of North American frogs. Pages 109-123 in M. J. Lannoo, ed. Amphibians Declines: The Conservation Status of United States Species. University of California Press, Berkeley and Los Angeles, California.

Ulmer, M. J. 1970. Studies on the helminth fauna of Iowa. I. Trematodes of amphibians. American Midland Naturalist 83:38-64.

Vandenlangenberg, S. M., J. T. Canfield, and J. A. Magner. 2003. A regional survey of malformed frogs in Minnesota (USA). Environmental Monitoring and Assessment 82:45-61.

Vanderburg, D. J., and R. C. Anderson. 1987a. The relationship between nematodes of the genus Cosmocercoides Wilkie, 1930 (Nematoda: Cosmocercoidea) in toads (Bufo americanus) and slugs (Deroceras laeve). Canadian Journal of Zoology 65:1650-1661.

Vanderburg, D. J., and R. C. Anderson. 1987b. Seasonal changes in prevalence and intensity of Cosmocercoides dukae (Nematoda: Cosmocercoidea) in Deroceras laeve (Mollusca). Canadian Journal of Zoology 65: 1662-1666.

Vanderburg, D. J., and R. C. Anderson. 1987c. Preliminary observations on seasonal changes in prevalence and intensity of Cosmocercoides variabilis (Nematoda: Cosmocercoidea) in Bufo americanus (Amphibia). Canadian Journal of Zoology 65:1666-1667.

Wilson, W. D., P. T. J. Johnson, D. R. Sutherland, H. Moné, and E. S. Loker. 2005. A molecular phylogenetic study of the genus Ribeiroia (Digenea): trematodes known to cause limb malformations in amphibians. Journal of Parasitology 91:1040-1045.

Werner, J. K., and K. Walewski. 1976. Amphibian trypanosomes from the McCormick Forest, Michigan. Journal of Parasitology 62:20-25.

Williams, D. D., and S. J. Taft. 1980. Helminths of anurans from NW Wisconsin. Proceedings of the Helminthological Society of Washington 47:278.

Woo, P. T. K. 1969. Trypanosomes in amphibians and reptiles in southern Ontario. Canadian Journal of Zoology 47:981-988. 